\title{
(Re-)modelling religious experience: some experiments with hymnic form in the imperial period
}

\begin{abstract}
Religious experience has been the topic of many different theoretical approaches. This paper starts from the premise that subjective individual experience is communicable only in terms of locally-available schemes, primarily linguistic, and thus ignores somatic signs such as ecstasy or frenzy. In the case of GrecoRoman Antiquity, this involves recourse to literary sources. The paper uses three Greek hymns of the imperial period, all of them experimental by comparison with "classical" models, to infer what we may call requisite rather than subjective experiences on the part of audiences. The hymns chosen are Mesomedes' Hymn to Isis (no. 6 Regenauer), the Orphic hymn to the Nymphs (no. 51 Ricciardelli) and the hymn to "Apollo" in PGrMag VI 30-38. The suggestion is that rhetorical analysis enables us to gain a mediated idea of the contrasting responses ideally evoked in the course of ritualized performance.
\end{abstract}

\section{Religious experience}

Until the 1980s, the dominant terms in which religious experience was discussed were subjectivist and attributivist/attributional. At any rate in the field of religious studies, this was largely due to the dual influence of Schleiermacher's evangelical Protestant intuitionism and William James' asymmetrical opposition between institutional and personal religion (cf. Proudfoot 1985, 9-40; 155-189); more recently, however, to social psychology (e.g. Hood 1995) and the various forms of phenomenology (Martin 2016, 526-528). ${ }^{1}$ Thanks to its simplicity, Rodney Stark's fourfold typology of religious experience, confirming, responsive, ecstatic and revelational, has been, and continues to be, influential (Stark 1965, cf. 1999). Resistance arose from two sides, cultural anthropology and the linguistic turn. Already in 1961 Godfrey Lienhardt, a pupil of Evans-Pritchard at Oxford, entitled his account of Dinka religion Divinity and Experience, which among other things tackled the issue

1 For a highly critical account of the influence of phenomenology on religious studies, particularly Rudolf Otto, G. van der Leeuw, Wach and Eliade, see Murphy 2010. Rappaport 1999, 391-395 (on Ultimate Sacred Postulates) reads to me like an attempt to save this sort of evaluative intuitionism. 
of how to represent the self-knowledge of a culture that not only had no conception of "mind" but no very clear ontology of divinity (1961, 147-170). Nevertheless, he argued persuasively that the Dinkas' "Powers" can be understood as images of complex experiences within their specific life-world. "With this knowledge, this separation of a subject and an object in experience, there arises for them also the possibility of creating a form of experience they desire, and of freeing themselves symbolically from what they must otherwise passively endure" (Lienhardt 1961, 170). It was, however, mainly Victor Turner's later work that spawned an entire movement in US cultural anthropology, the "anthropology of (mainly bodily) experience" (Turner and Bruner 1986). Despite the enormous success of this trend over the past three decades, it has not proved particularly interested in specifically religious experience (cf. James 2003, 181-210). Where this was attempted, it tended, at any rate early on, to produce efforts at intuitionist "insights", such as Turner's communitas (1974, 166-299), a reversion to Durkheimian collectivist apriorism, or the anti-rationalism of Bruce Kapferer's analysis of performance in major Sinhalese exorcisms (Kapferer 1986; cf. 1997), which, despite its impressive notation of ritual, often reads like the projections of a novelist. In the present context, therefore, I am more interested in the other form of resistance to authenticity-discourse, which was largely inspired by the linguistic turn (Martin 2016, 532-536).

Within religious studies, Wayne Proudfoot, without denying the possibility of Jamesian "experiences", emphasized the logical priority of the concepts and interpretative frames available for the very identification and formulation of experiences claimed as "religious", thus re-stating the most obvious socio-cultural conditions for the articulation of supposed mental events of this kind (1985, 190-227). A year or two later, Joan Scott, an historian critical of mainstream historical writing, emphasized historical discontinuities and the variety of local discourses that produce subjects and their experiences: "Experience is at once already an interpretation and is in need of interpretation" (1992, 37; cf. Fitzgerald 2000). Equally pertinent is the radical skepticism of an anthropologist such as Robert Sharf, who was inclined to doubt the referentiality of all reports of supposedly religious experiences, comparing such reports to the thousands of detailed "subjective" accounts of abduction by alien beings in the US in the 1950 s and 60s (1998, 108-109; cf. 2000).

Perhaps the most important recent discussion of religious experience, by Ann Taves, attempts to outflank pure constructivism by developing an analytical framework that includes special experiences both religious and non-religious (2009, 120-160). Here the framing of all experience is taken as read; it is rather the category "religion" that is questioned, moving away from theological or formal conceptions towards acceptance of what "interacting subjects viewed as emerging 
and how they decided to act on it" $(2016,6)$. Religious experience is not simply discursive but also embodied, and as such is neither stable nor fixed but a matter of how people decide on the meaning and significance of experiences. Taves' work seems to suggest that in the field of Religious Studies there is a continuing desire to save something of authenticity ("special experiences"), albeit via the detour of cognitive psychology and theories of group dynamics (cf. Fitzgerald 2010) .

Given the irremediable problems of evidence, however, the historian, especially the ancient historian, is better advised to start from the assumption that subjective individual experience, insofar as it is not purely staged as in Sharf's comparison, is at any rate communicable only via the relevant constructs available in a given culture or sub-culture. Conversely, for practical purposes, we can view these locally-available linguistic and schematic resources as not merely the frame but in effect the stuff of religious experiences. At its simplest, we can call this the "Rhine-postcard" phenomenon, as noted by the British tourist Michael Quin in 1843: the gorge between Koblenz and Bingen is where "the Rhine begins to look like itself” - i.e. where it begins to resemble the guide-books' descriptions of what it was supposed to look like (Quin 1843. 2, 116).

\section{Exploiting Greek hymns as evidence for "requisite" experiences}

Granted that "Greek religion" is a construction of post-Romantic scholarship, there is no denying that there survives a vast deal of evidence for what we at any rate view as religion, over a period of, say, 1,200 years, despite the fact that its practice and performance is irremediably lost. Much of this evidence is antiquarian and retrospective, much of the remainder oblique and by no means selfexplanatory. If we are to speak of "locally-available linguistic and schematic resources”, we need to focus on direct sources, namely first-order texts. In this paper, I suggest using Greek ǔ $\mu$ vo ("hymns”) experimentally for this purpose, which, as more or less complex songs in different forms directly addressed to named deities and performed in specific contexts perceived as related, directly or indirectly, to $\tau \dot{\alpha} \theta \varepsilon \tilde{\alpha} \alpha$ (ta theia, things relevant to the gods $\rightarrow$ "religion") (cf. Thraede 1994, 917-918), we can assume satisfy Taves' criterion of appropriate ascription (“deemed religious") (2009, 22-28). ${ }^{2}$ Whereas "ritual performance" is too

2 This formulation is intended to by-pass the discussion over the sort of distinction(s) to be made between "cultic hymns" versus "literary hymns": cf. Furley and Bremer 2001 (1), 2-6; Pòrtulas 2012, 235-240. 
amorphous/complex an entity to invoke (cf. Sax, Quack and Weinhold 2010), and is anyway, for lack of adequate materials, more or less unavailable in the context of antiquity, one can make a virtue of the necessity of taking texts alone. As the current surge of interest in Aelius Aristides' Hieroi Logoi attests, his hermeneutics of dreams, visions, and conversations provides by far the most sophisticated account surviving from antiquity of what can be done on the interface of complex schemes, tropes, self-staging and stimuli (e.g. Petsalis-Diomidis 2010; Downie 2013). The topos of epiphany, too, perfectly exemplifies the fluency with which cultic resources could be drawn upon in imagining divine encounters (Platt 2011; Petridou 2015).

My suggestion is that, given the sort of doubts about the accessibility of "experience" raised by Sharf, we might use Greek hymns to infer "requisite" experiences rather than "special" or "subjective" experiences. We might treat them as one (rather sophisticated) component of the multiple interpretative frames available for the identification and formulation of experiences claimed as "religious" within a specific context of practice. If we cannot have any direct knowledge of subjective states, analysis of such texts may, I suggest, give us an inkling of the responses intended to be evoked in the course of ritual performances. Although we can know nothing directly about these wider contexts, we can at least examine the surviving texts and make inferences from them. Of course in reality actual responses to these, at least those that were performed on at least one or more occasions, must have varied considerably (indeed, the "hymns" of the magical papyri assume a secret recital, with the addressee (the deity/ies) as sole auditor/s). But of that diverse reality again we can have no knowledge. It may be objected that such an approach presupposes reception, which I readily admit; but it does not presuppose specific audiences. Adopting the terms of reader-response theory, I take "requisite" experiences as those of an ideal reader/auditor, which can now only be approximated by a learned commentator armed with lexica, concordances and data-bases and alert to the danger of myopic "atomization" of the text (Shuttleworth Kraus 2002, 10-16).

Although cult-hymns cannot formally be distinguished from other lyric forms as regards their religious content, a pragmatic distinction can be made, inasmuch as they are a "form of worship directed towards winning a god's goodwill and securing his or her assistance or favor" (Furley and Bremer 2001 (1), $2-3)$. By virtue of its literary polish, the hymn has been likened to an ö $y \alpha \lambda \mu \alpha$, a "(god's) delight”, that aims to store up divine $\chi$ ópıs on behalf of the community that stages the performance (Race 1982, 8-10; Furley and Bremer 2001 (1), 61-63; Pòrtulas 2012, 234). As in the case of sacrifice, the gods themselves,

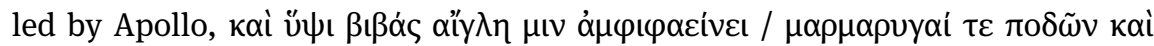

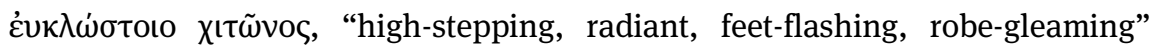


(HomHymn Apollo 202-203 Allen), model hymnic performance for human beings (cf. Lonsdale 1995, 30-31). Ideally, as Strabo emphasizes in a famous passage relating to the Kourêtes on Crete (Bremer 1998, 522-523), such performances took place in an atmosphere of relaxation and rejoicing:

It is a common characteristic of both Greeks and non-Greeks to perform religious ceremonies in an atmosphere of relaxed festivity, whereby some rituals are performed with 'enthusiasm' and some not, some with music, some without it, some only by initiates in secret, others in the open... Whilst it is well said that men imitate the gods best whenever they do good, it is perhaps more appropriate to say 'whenever they are happy'. And this happiness is found in gladness, in the celebration of festivals, in philosophy and in making music.

(Geogr. 10.3.9, 467C tr. H.L. Jones, with changes)

In the special case of healing-gods, Asklepios and his assistant Telephoros could be imagined as dancing for joy when a patient recovers (IG III.1 171 = Furley and Bremer 2001, 7.7.1 11.9-15). Indeed, the joy might extend still further: the Archaic poet Alkaios imagined nightingales, swallows and cicadas all singing to welcome the return of Apollo from the land of the Hyperboreans (frg. 307c19-22 Voigt = Furley and Bremer 2001, no. 2.1).

\section{Greek hymnic production in the Hellenistic and Roman periods}

It is generally thought that hymnic production greatly increased in the Hellenistic and Roman periods, ${ }^{3}$ with local literati routinely turning out songs (and music) for public performance. ${ }^{4}$ In many cities of the province of Asia and on the Black Sea coast there were formal associations of ù $\mu \omega \delta$ oi (hymnôdoi), of varying social catchment, from prominent - for example at Smyrna, where the son of a city-councilor records that he was hymnôdos both of Hadrian and of the gerousia, positions that he had inherited from earlier generations of his family

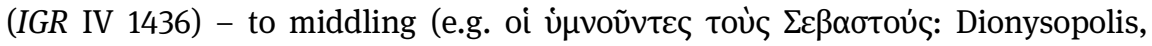
Moesia Inf.: IGBulg $\mathrm{I}^{2} 15[3]=30$ ). Although the precise organization is disputed,

\footnotetext{
3 A rapid but detailed overview in Lattke 1991, 37-39. Since this is not an epigraphic publication, I make no effort to cite the latest editions of inscriptions, but refer simply to familiar collections.

4 E.g. Kleochares of Athens: Syll ${ }^{3}$ 450; Glaukos of Marathon at Olympia (IOlymp. 457); a

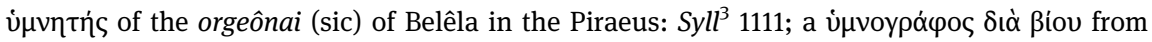
Laodikeia: IGR IV 1587 1.14-15 etc.).
} 
and altered over time, from the Julio-Claudian period they were formally responsible for staging and executing performances in individual cities in connection with all imperial celebrations, such as birthdays and victories (Halfmann 1990; van Nijf 1997, 165-167). To this end, such associations enjoyed civic, provincial and imperial subventions (e.g. IGR IV 1431 1.34-40) and are frequently included among the beneficiaries of euergetic gestures by the very wealthy (e.g. at Smyrna: IGR IV 1431 1.39; Miletos: IG XII 68 1.12; Ephesos: IEphesos Ia. 27 1.146; [267]). Their connection to the imperial cult prompted cities to set up copies of at least the imperial documents in a bid for status (IGR IV 1608 with Keil 1908, 103-104). Another major panhellenic institution requiring hymns was that of the organized Dionysiac technitai (Le Guen 2001). In many places there were local groups of singers, some ancient, such as the Molpoi at Miletos (Syll 57 with Deshours 2011, 276-293 no. 25) and the hymnôdoi of Artemis at Ephesos, some more informal, such as the numerous ephebic and maiden choirs, ${ }^{5}$ and Metroac (e.g. ILS 4164) ceremonies. An important series of 2nd-century CE documents from Klaros records the delegations sent each year by cities to the oracular temple of Apollo, including boys' and girls' choirs, sometimes mixed (SEG 37: 961-978). All of these institutions required a regular supply of hymns for performance, whether by groups or by solo performers. Especially notable productions were even thought worthy of inclusion in the local epigraphic assortment, sometimes with the approval of an oracle: there survive at least twenty hymns of various kinds inscribed on stelai, mainly at panhellenic centers, between the second half of the 4th century BCE and into the 2nd CE, two of them with musical notation. ${ }^{6}$ Although the range of styles and quality is very variable, all are simple in structure and tend increasingly to brevity (Parker 2012, 715).

5 E.g. Eleusis: Syll 885.27-30; Magnesia: Syll 695 with Deshours 2011, 197-208 no.1; Teos: IGR III 90.7-10); the paianistai of Asklepios in Munichia (Syll 1110 ); and performers who sang at various Isiac ceremonies (e.g. the hymns of Isidoros of Narmuthis [IMEGR 175]; Chaeremon frg. 10 van der Horst; Tibull. 1.7.37-48; RICIS 104/0206).

6 Most of these are treated in Furley and Bremer 2001. In their enumeration they are as follows:

Delphi: 2.3 (Aristonoos' hymn to Hestia); 2.4 (Aristonoos' paian to Apollo); 2.5 (Aristodemos' paian to Dionysos); 2.6.1 (?Athenaios' paian to Apollo); 2.6.2 (Limenaios' paian to Apollo, both with musical notation). Epidauros: 6.1 (paian to Asklepios, which survives in four slightly different versions, from Erythrai, Ptolemaios Hermion, Athens and Dion in Macedonia, though not from Epidauros itself); 6.2 (hymn to the Mother of the Gods); 6.3 (Ariphron's paian to Hygieia, copied on two different stelai and in two mss.); 6.4 (Isyllos' paian to Apollo and Asklepios, which was to be chanted three times while circling the altar); 6.5 (hymn to Pan); 6.7 (hymn to all the gods). Athens: 7.5 (Makedonikos of Amphipolis, paian to Apollo and Asklepios); 7.6 ("morning song" of 6 lines to Asklepios); 7.7.1 and 2 (two hymns to Telesphoros). We can add at least IPerg. II 324 (hymn to Zeus and other deities; for a recent discussion, see Várhelyi 2001, 26-30); the Cretan hymn to Antinoos (SEG 53: 1747bis = AE 1975: 832); and perhaps the "Berlin paian" 
At 156 lines, Philodamos' mid-4th century BCE paian to Dionysos is by far the longest; none of those dated to the imperial period is longer than 20 lines. $^{7}$ At the same time, the metrical structure tends to increasing complexity, to the point at which dactylic, lyric and iambic cola can all be used together, as in the late Hymn to all the gods, or traditional rules seem no longer to apply at all, as in the case of Makedonikos' paian.

Despite the almost total loss of ancient Greek hymns, and the multiplicity of sub-genres, we can safely say that traditionally the dominant content was mythical: the main exposition consisted of an evocation of one or more myths relating to the addressee, often relating his or her first advent or epiphany (Furley and Bremer 2001 (1), 18-19). Recent interest in the narrativity and narrative strategies of Greek hymns is grounded in this assumption (e.g. Faulkner and Hodkinson 2015). The paians of Philodamos and Isyllos (which is very much shorter) are still firmly in this tradition. Yet increasingly it is the imagined cultic setting of the hymn that takes precedence, the evocation of an ambience, a mood, an expectation. In place of narrative, we find experimentation in other modes, most explicitly in the case of Aelius Aristides' prose encomia of gods, which by that date were regularly termed "hymns" (Parker 2016, 67 n.1). Thus the first 13 sections of the earliest, the Hymn to Serapis, usually dated to the early 140 s CE, are devoted to an attack on the routinization of the usual run of metrical hymns:

There is nothing they do not dare or that presents difficulties for them (i.e. the poets). They treat the gods like puppets, and turn them into ordinary fellow-travellers, make them companions of human beings, even carousing with them and lighting their way with torches. And that is why I, as I said at the beginning, poets are so highhanded, so carefree, so 'easeful' as Homer puts it, when they compose hymns and paeans to the gods. In a couple of strophes or periods all is done: when they have said 'sea-girt Delos' or 'Zeus who delights in thunder', or 'the loud-roaring sea', and then have told in passing how Heracles came to the Hyperboreans and how Iamos was an ancient seer, or how Heracles slew Antaios, or when they have mentioned Minos, or Rhadamanthys, or the Phasis or the Ister, or have declared that they themselves are 'nurslings of the Muses' and 'unmatched in wisdom', they think their hymn quite good enough; and no ordinary person demands any more of them.

(§2-3, tr. Behr, heavily adapted)

(on papyrus): PBerol. $6870^{\mathrm{v}}=1: 52$ Heitsch $=\operatorname{TrGF} 2: 683$, which some have ascribed to Mesomedes (Bélis 2003, 232-234) but may rather come from an anonymous tragedy.

7 I omit here the literary and philosophical hymns, e.g. by Callimachus, Aristotle to Virtue, the Stoic hymn on the creation of the universe (SEG 28: $793=2007$ : 969), parodies (e.g. Lucian, Podagr. 129-137 etc.) and those composed for novels, e.g. Philostratos, Her. 19.14. $12-13$ Follet = p. 208 Kayser (to Thetis); 19.16.6-8 = p. 213f. (to Homer), that were not intended for performance in a cultic setting; cf. Regenauer 2016, $37 f$. 
Notwithstanding its traditional appropriateness in religious contexts, then, poetry tends towards the recycling of banalities that can provide only a general, abstract sense, whereas prose, with its advantages of clarity, coherence and discursivity, can purify religious language, an argument that links to Plutarch's earlier skepticism in de Pythiae oraculis 23-24 (405d-406f, cf. 403f1-3) of oracular utterance in poetic form (Pernot 2007, 176; 181-184). Among the banalities, evidently, is hand-me-down mythic reference. The use of prose for a hymn is thus for Aristides a strategy of defamiliarization as well as a demonstration of piety (cf. Russell 1990; Pernot 2007; Goeken 2007; 2016).

Although they are not in prose, much the same can be said of the three groups of hymns I propose briefly to discuss in the remainder of this paper, the hymns of Mesomedes of Crete (like Phlegon of Tralles and Aristomenes of Athens an imperial slave freed by Hadrian), the collection we call the Orphic Hymns, and the "hymns" embedded in some of the Greco-Egyptian magical papyri. Although these are all very different in detail, all seek to re-model the cult-hymn to their own ends by means of formal experimentation. This in turn suggested to me that such shifts of formal strategy might have implications for religious experience: instead of viewing these compositions solely in terms of their overt aim of attracting divine attention and favor, we might also consider their possible cognitive, emotional and intellectual effects upon performers and audience (who, in the case of the Orphic Hymns, may well have been identical), in short, in terms of their construction of specific kinds of religious experience.

\section{Three different experiments with the hymnic form}

The three groups of hymns have been chosen for their diversity, despite the fact that all (probably) belong, at least in their original form, to the 2nd century CE. ${ }^{8}$ The thirteen surviving poems ascribed to P. Aelius Mesomedes, a prominent lyric poet and citharode at the court of Hadrian and a personal friend of the emperor (Cassius Dio 77.13.7), are fragile, allusive compositions in literary Doric for solo

8 The date of the twenty-six hymns incorporated into the longer Greco-Egyptian receptaries is conjectural, since in their surviving form they were only (re-)copied in the late 3rd and 4th centuries CE; however, although no parallel versions are known from other sources, and it is impossible to re-create the "originals", they are probably based on earlier compositions, no doubt of the first two centuries CE, possibly even earlier (Furley 1995, 39-40; Brashear 1995, 3420; Bortolani 2016, 28-29). 
performance, intermediate between the literary epigram and lyric poetry. ${ }^{9}$ Ignoring two very brief introductory addressees, only four of the surviving texts are hymns, though the poem to the Adriatic Sea (no. 6 Heitsch) uses hymnic topoi

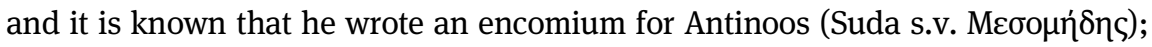
other poems are verse riddles and fables - one is on an astronomical orrery (cf. Brumbaugh 2015, 166).

Whereas Mesomedes was celebrated in antiquity (his work was imitated by Synesius, for example), no extant ancient source cites our Orphic Hymns (Morand 2001, 90), although they constitute the only known ancient "hymnbook". Whereas the Hymns betray knowledge of Orphic-Bacchic lore, and various forms of Dionysos are prominent, ${ }^{10}$ their "Orphism" is sui generis, since none of them mentions any of the classic Orphic themes - the dismemberment of Dionysos by the Titans, the soul being trapped in the body so that death is a welcome release, underworld torments - so it is best to emphasize the diversity of "Orphism" and maintain simply that the collection is "Orphic" inasmuch as the group or groups who produced the hymns chose to consider Orpheus as their author (Rudhardt 2008, 167-168; Herrero de Jáuregui 2015, 229-232, cf. Morand 2001, 94). Hymns attributed to Orpheus had after all been current since at least the 5th century BCE (Euripides, Alc. 357-360, cf. PDerveni col. XXII 1l.11f. p.22 Jourdan). Although in some cases they are clearly based on earlier material (e.g. in relation to Zeus: Bernabé 2010, 68), the Hymns affect an idiosyncratic style that pushes some current hymnic developments, above all asyndeton and polysyllabicism, to their limit.

The circulation of the Greco-Egyptian "magical hymns" was likewise tightly restricted. With one or two exceptions in "activated" texts, they occur as elements within longer recipes (praxeis) contained in formularies whose contents derive from a ritual practice ultimately based on temple learning, although the actual practitioners are assumed to be working elsewhere, perhaps in the quarters reserved for temple-workers, perhaps in the village or urban area beyond. In the absence of close analogies, we can only say that they represent a fluent synthesis of Greek and Egyptian hymnic models, thoroughly integrated into their contexts by means of the introduction of voces magicae, the esoteric "names" whose utterance was deemed to provide direct access to the other world (Bortolani 2016, 32-38). They seem mainly to have been adapted, perhaps many times over, from Greek texts in honor of "classic” Greek gods, such as Apollo, Hermes, Aphrodite,

9 Cf. the succinct overview by Bélis 2003. Only two poems (nos. 11-12 Heitsch) are explicitly stated in the ms. tradition to be by Mesomedes (see e.g. Regenauer 2016, 17-19; 87-92). There are however fairly good grounds for ascribing the others to him.

10 Ricciardelli 2000b; 2008, 332; Jiménez San Cristóbal 2008; Morand 2015, 219-222. 
or Helios, circulating in Egypt, whereas others, particularly those that display considerable familiarity with Egyptian theological concepts, especially those to Typhon-Seth, or address night-powers such as Artemis-Selene-Artemis, may have been composed directly by bilingual Egyptian priests.

\subsection{Mesomedes}

For reasons of space, ${ }^{11}$ it seems best to illustrate Mesomedes' technique by means of the brief Hymn to Isis (no. 5 Heitsch = no. 25 Totti = no. 6 Regenauer), one of two hymns known only from cod. Ottobon. gr. 59 (0), in cretics interspersed with "palimbacchei", but unfortunately without the accompanying musical notation:

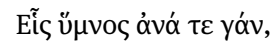

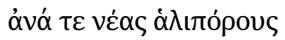

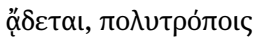

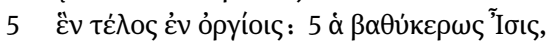

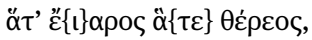

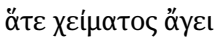
veoyóvous ìvías.

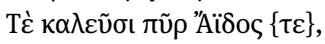

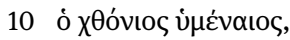

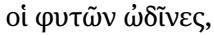

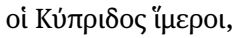

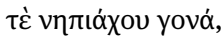

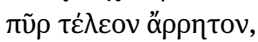

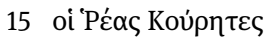

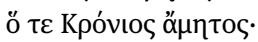

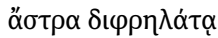

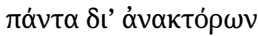

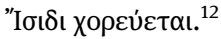

One single hymn is sung/ on land and/ on the seafaring ships,/ just one addressee in many rites:/ long-horned Isis, who holds/ the neonate reins/ of Spring, of Summer,/ of

11 Brumbaugh 2015, 174-181 chooses the Hymn to Helios and To the Adriatic for a similar purpose.

12 For the numerous editorial interventions, see Regenauer's apparatus (p. 251). At the begin-

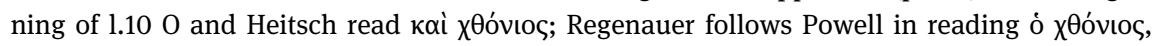

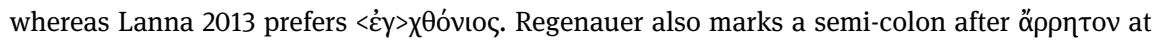
the end of 1.14, and understands the Kurêtes and Kronos' harvest as dancing, like the stars. Here I follow Heitsch, Totti and Lanna 2013, all of whom understand them as part of the list starting in 1.9 and mark the break after ö $\mu \eta \tau$ то. 
Winter./ Light of Hades, chthonic marriage-rite,/ the birth-pangs of plants,/ the desires inspired by Kypris,/ the birth of a baby,/ mystic fire unspeakable,/ Rhea's Kurêtes,/ and Kronos' harvest / - (all) call upon you!/ The stars all dance/ over holy places/ for Isis in her car.

Despite their wide generic variety, Greek hymns have traditionally been understood as manifesting a tripartite structure, invocation, exposition ("pars epica"), request ("precatio") (Wünsch 1914, 144-145; Furley 1993; Hopman-Govers 2001, 35-36). More recently this division has been replaced by invocation, praise (which may include predication of powers, anaphoric address, reminders of earlier benefits, descriptions of the god and his doings, narratives) and the climax, prayer (including petition) (Furley and Bremer 2001 (1), 50-64). In this case, however, Mesomedes neatly avoids narrative altogether, combining an allusion to the

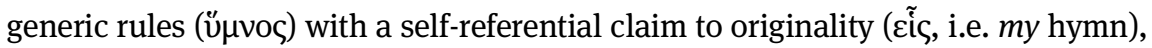
a hymn that is both uniquely fitting and all-comprehending - he manages at the same time to allude both to the spelling Eĩos of the aretalogies and to the megatheistic acclamation عí $\theta \varepsilon$ ó - even as it rises both from land and sea. Though a trope for "everywhere", "land" and "sea" also evoke Isis as inventor of farming and founder of temples as against her maritime epithets, Pharia, Euploia, Pelagia and the major Isiac festival outside Egypt, the Ploiaphesia/navigium Isidis, celebrated on March 5th. At the same time, the twice-repeated switch from One to Many in 1l.1-4 evokes Isis myrionyma (Bricault 1996, 11-75).

Although Mesomedes nowhere expressly thematizes Isis' Egyptian identity,

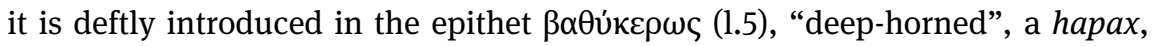
whose first five letters initially arouse expectations of appropriate epithets, say $\beta \alpha \theta$ v́ко $\lambda$ тоৎ (deep-breasted, implying fertility and fecundity, e.g. of Gê and the

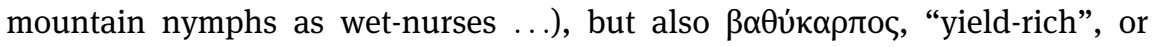
$\beta \alpha \theta v \kappa u ́ \mu \omega v$, "deep waved", but whose finale is deliberately mystifying to anyone whose idea of Isis is formed by the Hellenistic iconography - say the auratic statue in black and white marble in the Kunsthistorisches Museum in Vienna (Gschwantler 2005): "horns? - what horns?" The image “deep-horned" is fitting only for those familiar with late-period Egyptian images of Isis-Hathor suckling Horus-the-Child, that is, those who have actually been to Egypt, not to those who know only the Isis with mini-horns occasionally found in Roman art. This hint at Egypt as other is immediately reinforced by an enumeration of the only three seasons, spring, summer and winter, recognized there (Diod. Sic. 1.26.5), whose imperceptible transitions are induced by Isis' motherly tenderness (veóvous jंvías, 1.8). Mesomedes' goddess is not so much a syncretistic as a polymorphic, polysemous deity (Malaise 2005, 193-99).

There follow eight lines in almost perfect asyndeton (except for minimal $\tau \varepsilon$ in 11.13 and 16), deftly intimating the contents of that other, imaginary, hymn, 
evoking now this, now that Isiac presence - in this world, in the Underworld, in the mythic past. Here the most fitting adjective is "exquisite" - against the 57 clod-hopping lines of the Kyme aretalogy (Totti 1985 no.1 = RICIS 302/0204 etc.), to say nothing of the almost 300 lines of the Oxyrhynchus version (POxy $1380=$ Totti 1985 no. 20) or the 178 lines of the verse hymn from Andros (Totti 1985 no. 2 = RICIS 202/1801), Mesomedes works in miniature, like one of the outstanding Greek intaglio-cutters of the Principate - Dioskurides, or his son Eutyches, or Euodos, or Thamyras. As such, he can hint transhistorically at grand themes through specific details, the slow unfolding of leaf buds and flowers ( $\varphi v \tau \tilde{\omega} v$

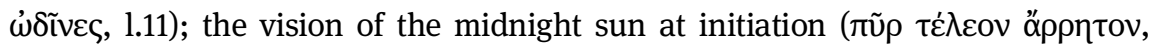
1.14); the para prosdokian whereby, in contrast to Callimachus, Hymn to Zeus 52-54, the Kurêtes - appropriate because of the identification of Isis' mother Nut as Rhea - serve not to introduce the child-eating Kronos, but a quite different one; the neat rapprochement between the function of Isis-Renenutet-Thermouthis as bestower of bountiful harvests and the Greek identification of Isis' father Geb as Kronos (cf. Plutarch, De Iside 12, 355f1-2), lord of the golden age, when the

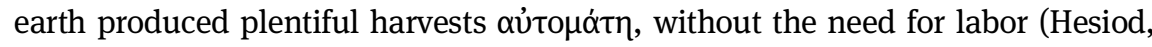
Op. 118 Solmsen).

As a citharode, then, Mesomedes uses the privilege of performing to a restricted audience in a rarified genre to offer his own polysemous GrecoEgyptian Isis, the goddess whose power discreetly suffuses time, space and nature, by dismantling generic rules, dispensing with constatives, and working through hints and allusions (cf. Psaroudakes 2018). This, he suggests, is truly the way to intuit and experience such a deity. The Mesomedean cliché of the astral dance (1.19), evoking the clear night sky, omits all mention of the Moon. But the audience is assumed to be aware of its/her presence.

\subsection{The Orphic Hymns (hereafter HO)}

The $H O$ consist (now) of 87 brief hexametric hymns, ${ }^{13}$ none longer than 30 lines, addressed to 87 different deities. ${ }^{14}$ A manuscript brought to Rome from Constantinople in 1423 by Giovanni Aurispa seems to have served as the basis

13 Quandt 1955 remains the standard text, despite its problematic punctuation; Ricciardelli 2000a is an excellent full commentary with translation; the Budé (Fayant 2014) also offers a serviceable tr. with a useful introduction. The best discussions for my purposes are Morand 2001; Ricciardelli 2008; Rudhardt 1991; 2008.

14 Rudhardt 2008, 183 counts 25 short hymns (6-9 lines); 45 medium-length (10-14) and 17 long hymns (16-30 lines). 
of the four traditions known from later copies (Quandt 1955, 1-46*; Ricciardelli 2000, xlvi-xlvii; Morand 2001, 33-35). Many of these include $H O$ with the texts of (at least) the Homeric Hymns, Callimachus' hymns, the Orphic Argonautica and Proclus' hymns, thus establishing a Humanist "classical" genre that was completely discredited with the rise of scientific philology. It is in fact mainly the re-invention of Orphism, with the "publication officieuse" of the Derveni papyrus (1962) and the Bacchic-Orphic lamellae on precious metal (etc.), that has led to a recent surge of scholarship (Morand 2015, 209).

It is routinely observed that the hymns of $\mathrm{HO}$ display a unified style and manner, drawing upon Homer and Hesiod but adding lexis, grammar and expressions from Classical, Hellenistic and imperial-period poetry. This has led some, most recently Graf, to claim that they were all composed by the same person (Graf 1992, 161). More recent scholarship has tended to doubt this (Hopman-Govers 2001, 37; Rudhardt 2008, 223, 230), and it is certain that the proem (عủý), which purports to be an address by Orpheus to Musaeus, has been cobbled on, since, among the 70 divinities listed, it mentions several, such as Eniautos, Atlas, Aion, Chronos etc., who are not represented by a hymn in the collection, and omits at least ten, including Protogonos, the Moirai and Nemesis, that are. Moreover in modern editions the proem as represented in the ms. tradition has been shortened by ten lines now assigned to a Hymn no. 1 (to Hekate), although no such heading appears in the mss. ${ }^{15}$ Further evidence of ancient editorship and design is provided by the clear sense of organization: the collection proceeds through a sequence of themes, beginning with primordial Orphic divinities (2-6: Prothyraia, Night, Ouranos, Aither, Protogonos), moving on to cosmic order (7-11) stars, Helios, Selene, Physis, Pan); representatives of the Old Order (12-14: Herakles as Titan, Kronos as husband of Rhea, Rhea); the New Order (15-18: Zeus, Hera, Poseidon, Pluto) and so on, through a central section mainly devoted to manifestations of Dionysos (42: Misê, 45-47: Dionysos Bassareus Trieterikos, Liknitês, Perikonios, 52-53: Trieterikos, Amphiêtês), then a large miscellaneous group, and ending with Hestia, Hypnos, Oneiros and Thanatos (84-87) (Ricciardelli 2008, 330-332).

It is for this reason that Morand observed that it makes no sense to read just one hymn by itself $(2001,98)$. Whether that allows us to infer a coherent liturgical procedure, moving between this lighted altar to the next, with "real" apparitions of deities, and terrifying experiences, as Graf has suggested, may be doubted (2009, 175-181; contra: Rudhardt 2008, 181). It is clear enough that

15 The mss. headings commence with Prothyraia, "She before the doors", i.e. Artemis Eilithyia; see Ricciardelli 1995; 2008, 327-330. 


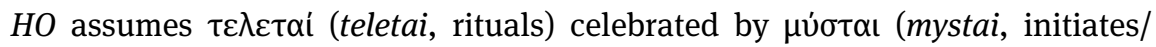
worshippers), ${ }^{16}$ and the discovery of scattered altars to Misê, Hipta/Sabazios, and Dionysos Êrikepaios in west-central Asia Minor clearly indicates a movement that grew up in that area (Morand 2001, 169-181, 189-193), no doubt initiated by a charismatic mystagogue in the Weberian sense. As for the probable date, Wolfgang Fauth hazarded the guess that $\mathrm{HO}$ is roughly contemporary with Plutarch (1983, 2264), while Morand, excessively reliant on parallels with the lexis of Nonnus, offered 2nd to 5th century CE (2001, 304). Most recently, it seems to have become usual to settle for a date in the Antonine period (e.g. Herrero de Jáuregui 2015, 224).

$\mathrm{HO}$ retains vestiges of the traditional hymnic structure, in that the first-person orant briefly invokes the addressee, and at the end outlines a very brief, indeed schematic, request, for health, peace, security, wealth and prosperity, that is, the usual stereotyped this-worldly benefits, though the Clouds (21) are asked for rain,

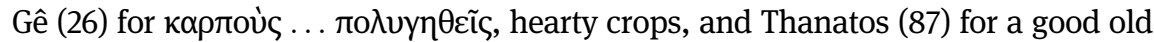
age (Hopman-Govers 2001, 41; Ricciardelli 2008, 340-341; Morand 2001, 309-317). Except in the short hymns such as nos. 49, 75, 80, 82, where invocation merges directly into the request, the central "praise" section is, as in the standard scheme, much the longest, but consists almost entirely of descriptive adjectives and participial phrases in asyndetic style. ${ }^{17}$ A good example is the hymn to Eleusinian Demeter (40):

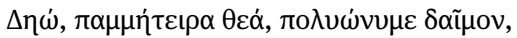

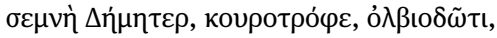

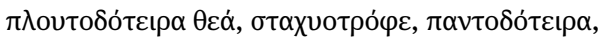

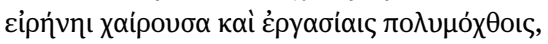

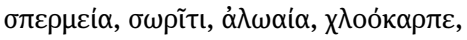

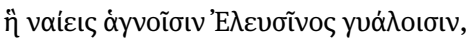

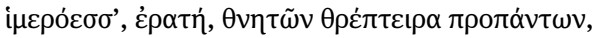

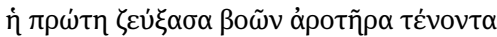

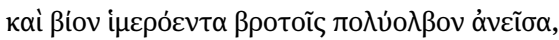

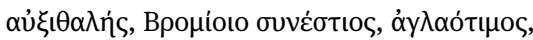

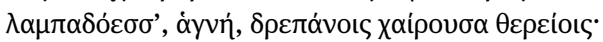

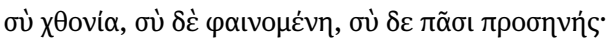

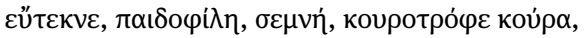

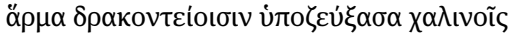

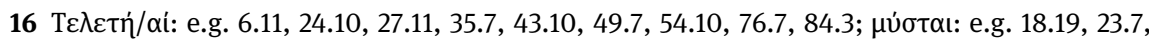
$34.27,50.10,52.13,56.12,57.12,61.10,71.12,75.5,84.3$. The gods are often invited to take part in these celebrations: Ricciardelli 2008, 333-335.

17 A variety of other techniques, for example phonic effects (alliteration, assonance), etymologization, and paradox, are discussed by Morand 2001, 61-68. 


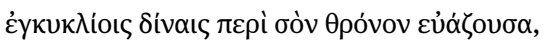

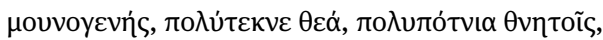

ท்

An English translation captures none of this asyndetic brilliance:

\begin{abstract}
Deo, divine mother of all,/ goddess of many names, / revered Demeter, nurturer of youths, / giver of prosperity and wealth,/ you nourish the ears of corn,/ O giver of all,/ you delight in peace,/ and in toilsome labor,/ present at sowing, heaping and threshing,/ O spirit of the unripe fruit,/ you dwell/ in the sacred valley of Eleusis,/ charming and lovely,/ you give sustenance to all mortals;/ you were the first to yoke/ the ploughing ox,/ the first to send up from below a rich,/ a lovely harvest for mortals./ You are growth and blooming,/ O illustrious companion of Bromios,/ torch-bearing and pure,/ you delight in the summer's yield. From beneath the earth you appear,/ gentle to all,/ O holy and youth-nurturing lover of children and of fair off-spring./ You yoke your chariot/ to bridled dragons,/ round your throne/ you whirl and howl in ecstasy./ You are an only daughter, but you have many children/ and many powers over mortals;/ the variety of flowers reflect/ your myriad faces and your sacred blossoms ....
\end{abstract}

(tr. Athanassakis)

There are some exceptions to this model, such as 68 (Hygeia) and 87 (Thanatos), where virtually no epithets are used, and some complex examples, such as 18 (Pluto) and 34 (Apollo), where we find mythic allusions and references to favorite haunts, as in the classic praise-formula, but essentially $\mathrm{HO}$ achieves its singular effects by dense accumulation of epithets and short phrases. ${ }^{18}$ What interest me most of all in this connection are the compound adjectives. Although the use of this technique becomes common in Alexandrian poetry (especially Lycophron) and, later, Quintus Smyrnaeus and Oppian, in no extant Greek text is it deployed with the same intensity as in $\mathrm{HO}$. The following list was drawn up by Jean Rudhardt (2008, 220-235), who alone has analyzed the compound epithets in detail: ${ }^{19}$

1) several dozen are taken over from the epic plus Hesiod, including the Homeric Hymns in particular, as part of the strategy of timelessness; these

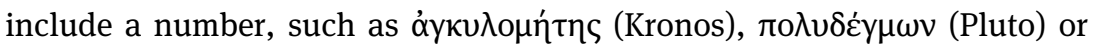

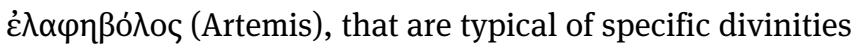

18 Hopman-Govers $(2001,36)$ provides a list of later Hellenistic and imperial-period texts that rely heavily on this technique, including AnthPal 9.524 (to Dionysos) and 525 (to Apollo) (both anonymous), which consist entirely of epithets arranged in alphabetical order, each of the 24 lines containing four epithets beginning with the same letter. Such jeux d'esprit imply a sophisticated awareness of the dangers of trivialization.

19 Bernabé's concordance (1988) is indispensable here. 


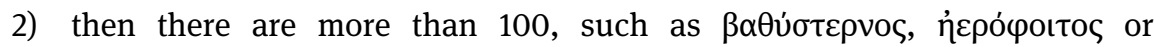
$\sigma \varepsilon \lambda \alpha \sigma \varphi$ ópos that are attested first in Classical authors

3) plus several dozen that, so far as we know, occur first in Hellenistic authors, including the Garland of Philip etc.

4) a restricted number known only from epigraphic and papyrological sources, mainly of imperial date

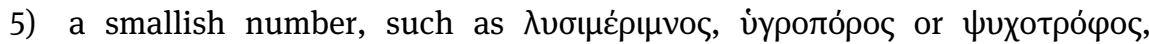
known only from authors of imperial/late Roman date, such as Oppian, Nonnus, Synesius, Gregory of Nazianzen, and the later writers assembled in the AnthPal. ${ }^{20}$ This leaves

6) no less than 140 compound adjectives that so far as we know are coinages of $\mathrm{HO}$ and found nowhere else, in other words, hapaxes of one sort or another, sometimes calqued on earlier compounds (listed in Rudhardt 2008, 225-229). And

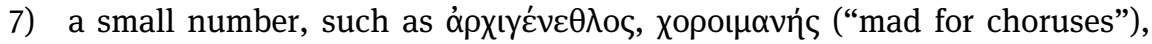
$\pi u p i \delta \rho \mu_{0}$, that are only otherwise found in Orphic texts.

Whereas once Richard Wünsch could complain about "die endlosen Ketten” of epithets in $H O(1914,145)$, it has now become usual to stress the diversity and subtlety of the effects achieved by this "forme extrême de concentration" in achieving the overt aim of pleasing the gods (Hopman-Govers 2001, 37). Abundance, exhaustiveness, precision, grandeur, creative tension are some of the rhetorical aims that we can point to (Morand 2001, 72-76). The common view, which is surely at least partly true, is that, through the deployment of these and other performative techniques such as music and dancing, performers and audience felt "subsumed into divine company for the brief span of their celebration" (Furley and Bremer 2001 (1), 16; cf. Lonsdale 1995, 32-33). I want rather to suggest that the hypertrophy of rhetorical effects, and the multiplicity of compound adjectives in particular, constructed a complex, highly-differentiated experience of divinity that responded to the requirements of the self-image of a group that considered itself in every way elect and apart.

Of the many passages one might invoke, I take exempli gratia a section of the hymn to the Nymphs (51):

20 Given the uncertainties of survival, Rudhardt agrees $(2008,223)$ that these are not to be given too much weight with regard to the issue of dating $\mathrm{HO}$. On the importance of postTrajanic hexameter poetry, including Dionysius Periegetes, for Nonnus see e.g. Whitby 1994, 105-107. 


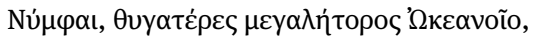

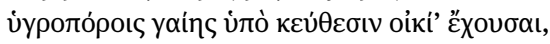

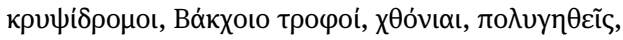

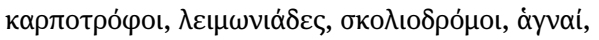

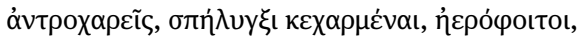

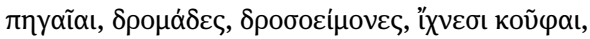

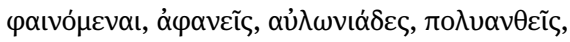

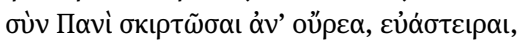

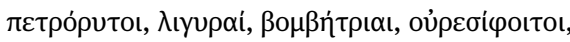

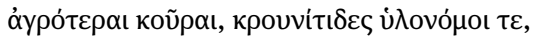

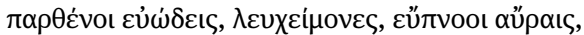

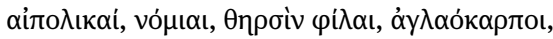

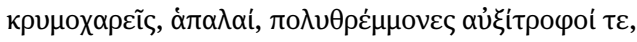

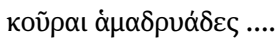

O Nymphs, daughters of great-hearted Okeanos,/ you dwell inside the earth's damp caves;/ you are as secret as your paths, 0 joyous, $\mathrm{O}$ chthonic nurses of Bacchos./ You nurture fruits, you haunt meadows, $\mathrm{O}$ sprightly and pure / travelers of the winding roads, who delight in caves and grottos./ Swift, light-footed and clothed in dew, you frequent springs,/ visible and invisible, in ravines and among flowers,/ you shout and frisk with Pan upon mountainsides,/ gliding down on rocks, you hum with clear voice./ O mountain-haunting maidens of the fields, of gushing springs and of woodlands, sweet-smelling virgins, clothed in white, fresh as the breeze,/ herds of goats, pastures, you protect; wild animals love you./ Though you are tender, cold delights you; you feed many, you help them grow,/ Hamadryad maidens ...

(tr. Athanassakis)
\end{abstract}

It is virtually impossible for a modern western language to reproduce the insistent staccato rhythm created by the pitiless succession of vivid, evocative ideas in the Greek - one can only say that the combination of bathos and gushing paraphrase in Athanassakis' version is very unfortunate. ${ }^{21}$ As a whole, the hymn seeks to maintain a constantly renewed tension between the points of fecund, dark wetness, light aëry joy and the disturbingly uncanny, darting rapidly from one crystalline thought to another, now evoking epic, now contemporary poetic usage, and skillfully interweaving allusions to the arch-shapeshifter Dionysos. I see this as an attempt to communicate a vision of a complex, never to be comprehended, divine reality, a vision that, through being committed to memory via repeated performance, becomes the experience of these divinities that the worshipper internalizes - an experience that is itself brilliantly facetted, elusive and

21 The version by Jacques Lacarrière in the series La Salamandre (1995) is much more successful. 
yet pregnant with possibility. The hymn can be imagined as a sort of Antonine Virtual Reality headset, at once super-real and totally phantasmagoric.

One of Jean Rudhardt's suggestions was that, notwithstanding the device of epiclesal polychromy, individual lines in $\mathrm{HO}$ tend to carry consistent images or thoughts $(1991,267)$. This is surely sometimes the case, but no less often, the associations are deliberately discontinuous, negating the desire for semantic continuity and development. In the case of no.51, such discontinuity fits perfectly both with the fiction of multiple Nymphs/multiple races of Nymphs (itself a knotty problem for a short text) and with the hymn's ambition to represent them in perpetual movement and flow - a motion at once counteracted by the insistence on fixity and locality. Other major contrasts are between high and low, light and dark, confinement and freedom, sound and silence, the tamed and the wild, mythic memory and joyful presence. It is precisely in the unresolved tensions between these binaries that the religious experience is formed, a never-ending series of aporiae, a figure for the central aporia, the knowledge of god in a highly complex polytheistic system (cf. Sfameni Gasparro 2013, 440f., 446), an attempt to rise to the challenge of reversing and gainsaying the deadening routinization inherent in ceremonial performance in the context of civic religion.

In order to suggest how such a hymn effects its "VR-function", I just take a closer look at the first few lines of $51 .^{22}$ The topography starts deep and wet: the Nymphs are said (1.1) to be daughters of Okeanos, not a widespread idea, but $\mu \varepsilon y \alpha \lambda \eta \dot{\tau} \tau \rho$, "of grand emotions", plus proper name reassure - this is an Homeric device. ${ }^{23}$ The wetness implied by this parentage becomes explicit at the start of 1.2: ن́ypoлópoıs, ambivalent between "wet-pathed" (cf. Homeric

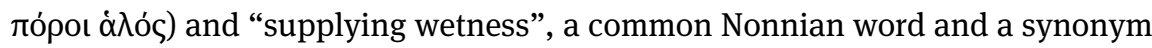

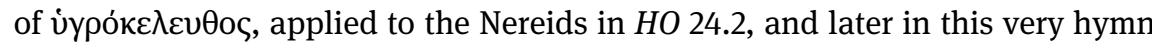
to the Nymphs themselves (1.14); and its domestic comforts for these creatures

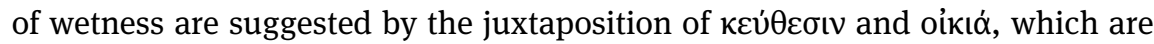
grammatically unrelated but evoke the expression $\kappa \varepsilon \tilde{v} \theta 0 \varsigma$ olk $\omega \nu$ for the interior of a house (e.g. Eur., Alc. 872). The twofold thought of darkness and movement is picked up in the first word of 1.3, $\kappa \rho \cup \psi i \delta \rho o \mu \mathrm{ol},{ }^{24}$ but immediately reduced to its first semantic component in the reference to looking after baby Dionysos to

22 Ricciardelli's commentary is indispensable (2000, 428-432). I do not here emphasize the semantics of the compound epithets, though they add another crucial level of tension.

23 But note Dionysius Periegetes, Orbis descr. 658 (Hadrianic).

24 Casaubon wanted to make this word pick up the reference to the house and proposed

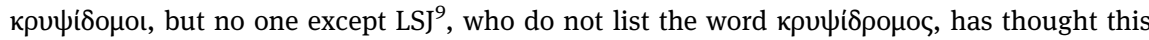
was a good idea. 
keep him safe from Hera; ${ }^{25}$ then back to the underworld with $\chi \theta$ óvı $\alpha$, followed

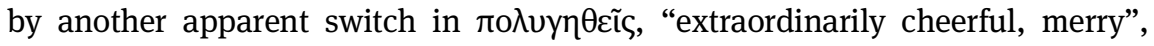
which is elsewhere in $H O$ used of the effects produced by Hygeia (68.4), and here

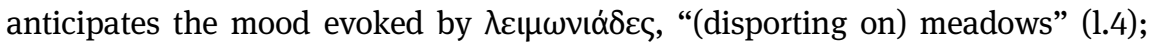
but it also refers back to Dionysos, since the word is used of him twice elsewhere in $H O(44.3 ; 75.1){ }^{26}$ A hidden reference to Dionysos (as god of shooting vegetation) provokes the next epithet, at the beginning of 1.4, картотро́ $\lambda \varepsilon \Perp \omega \nu เ \alpha \dot{\delta} \delta \varepsilon \varsigma$ brings us up from the damp depths into the sun-filled world of culti-

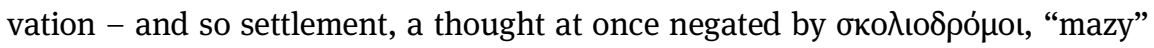
(cf. Spenser's "the mazie thickette")/"sinuoso", which reverts back to the restless-

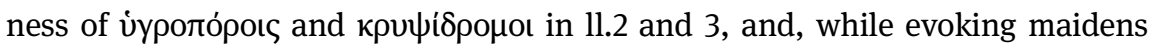

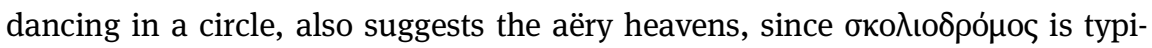
cally applied to the changes of the moon. L.5 amplifies this paradox by juxtaposing two words evoking caves (so back to the underworld, damp and darkness),

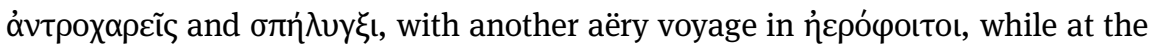

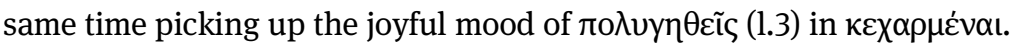

Many hymns in $H O$ can be analyzed in a similar manner. By shifting our emphasis from their "social" or overt aim, and thinking back to the Rhine postcard, we can begin to disengage the sense, important for the LAR project, in which each of them constructs its own specific religious experience over time.

\subsection{Greco-Egyptian “magical” hymns}

Once again, given constraints of space, I confine myself to providing a single, fairly representative, example of the hymns that were included by the authors and/or editors in their instructions for the performance of complex ritual procedures for a variety of ends. The following text is part of a longer hymn to Apollo that has been broken up into sections and spliced with voces magicae, and forms part of an elaborate request for a dream oracle. In this case, the papyrus partly reproduces the metrical scheme but ignores it when it seemed appropriate to insert voces magicae:

25 This allusion is amplified in 1l.15-16, just before the request, where the Nymphs are called "Nysaean" (cf. HomHym Dion.26.3-5; also Hom., Il. 6.132-133).

26 HO 51 is placed right among the Dionysiac hymns. The association between D. and $\pi о \lambda$ $ү \eta \theta$ ńs is ancient, first found in Hes., Theog. 941 (with West's note). In this connection it of course evokes the pleasures of wine, and suggests the Nymphs may also double as bacchantes. 


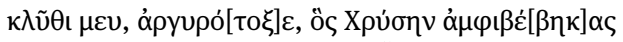

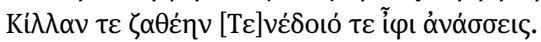

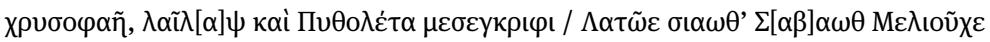

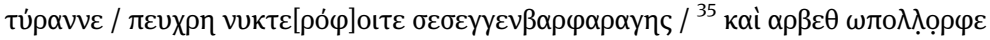

$\varphi \iota \lambda \alpha i \mu \alpha \tau \varepsilon \alpha \rho \beta \alpha \theta \imath \alpha \omega$ /

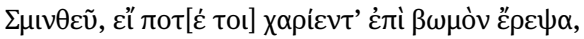

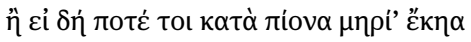

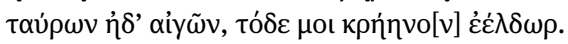

PGrMag VI $30-38 .^{27}$

Pay heed to me, Silverbowed, protector of Chrysê and divine / Killa, and mighty Lord of Tenedos, // golden-gleaming [vox magica], ${ }^{28}$ and Pythôn-slayer, [vox magica] / son of Letô [vox magica], Sabaôth, Meliouchos, Lord / [vox magica], night-rover, [vox magica], / and [2 voces magicae], ${ }^{29}$ blood-relisher, [vox magica] // Smintheus, if ever I have piled the joyful altar high for you, / or burned for you the fat thighs of choice oxen or goats, then fulfil this desire of mine.

We happen to know that the five hexameter lines, except for the word $\beta \omega \mu$ ov (1.36), are taken directly from the prayer in Iliad 1.37-41 to Phoibos Apollo uttered by the Trojan Chryses, the god's priest, who has been wronged by Agamemnon, a prayer that is at once answered by the god, who fires deadly arrows into the Achaean camp and causes a pestilence to break out. They represent therefore a crasis between two common resources of the magical papyri, the historiola, a mythical allusion or mini-narrative (Frankfurter 1995), and the deployment of Homeric citations, that is, words hallowed by centuries of repetition and re-contextualization, as inherently effective utterances (Karanika 2011).

27 There are several uncertain readings (see also Kenyon 1893, 82 no. XLVII); I have mainly followed Preisendanz. Reproduced in PGrMag 2: 244 as Hymn III 11.30-38 (Heitsch), and somewhat differently by Bortolani 2016, 192 (her Hymn 8). Both present all the lines as though they were metrical. It has recently been recognized that the text (= PLond I $47=$ PGrMag VI), which consists of a single sheet cut off a roll, is in fact the missing beginning of PBerol. $5026=$ PGrMag II (see following note).

28 Although $\lambda \alpha \tilde{i} \lambda[\alpha] \psi$ could be a Greek word ("whirlwind"), it is not an Apollonian epithet, so that it is more appropriate in the context of a succession of epithets each "qualified" by a vox magica to understand it as $\lambda \alpha \ddot{\prime} \lambda \alpha \mu$, itself found in the form $\lambda \alpha \ddot{\prime} \lambda \alpha \mu \psi$ at PGrMag II 117f. (relevant in that PGrMag VI is the lost beginning of PGrMag II) in the same sequence of Apollonian recipes, and XV 15 (cf. Bortolani 2016, 195).

29 I follow Preisendanz in taking $\alpha \rho \beta \varepsilon \theta \omega \pi о \lambda \lambda \rho \varphi \rho \varphi \varepsilon$ as a pair of voces, the latter apparently a

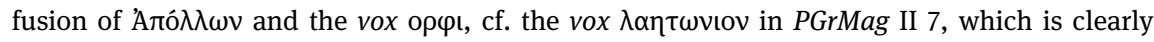

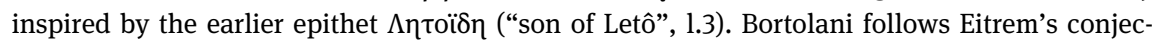

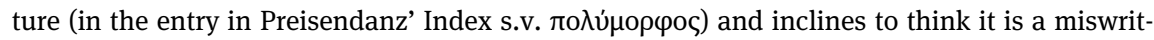
ing or misunderstanding of that adjective in an earlier version (2016, 197-198). 
This quotation, in itself a source of authority, has been "re-charged" by the insertion of 11.32-35, which begin as a pastiche of Apollonian epithets ( $\chi \rho v \sigma o \varphi \alpha \tilde{\eta}$, $\Pi v \theta 0 \lambda \varepsilon \dot{\tau} \alpha, \Lambda \alpha \tau \tilde{\omega} \varepsilon),{ }^{30}$ segue into a sequence of names/epithets associated with

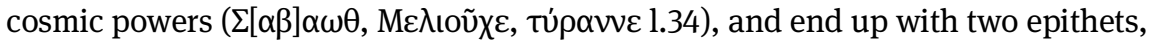

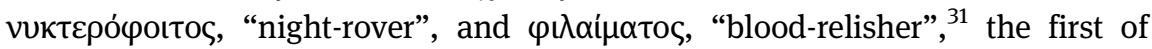
which anticipates the later invocation of Paian Apollo, who "controls this night" (PGrMag II 8), while the second serves to link the preceding re-classification of Apollo to the blood-sacrifice that follows in Chryses' prayer.

Although the original prayer had nothing whatever to do with divination, it has been effectively appropriated for its new purpose. The adjectival insertions by the author of the praxis are far from willful, since they re-contextualize the Homeric citation in order to embed it within a quite different "syncretic" thematic horizon, in which "Apollo" is mere cipher for a transcendent power, which can be activated by the succession of voces whose mere utterance takes over, usurps, each adjective in turn. The inclusion of Greek verse invocations into the complex praxeis of some practitioners is to be seen both as an open acknowledgement of the fact that Greek metrical incantations had historically played a significant role in creating the very practice of Greco-Egyptian "magic" in its developed form (Faraone 2000), i.e. a claim to the possession of a certain cultural capital, but also as a strategy of relativization, inasmuch as the anonymized texts are treated as so much raw material to be dismembered and adapted as suited the contingent aims of the author.

\section{Conclusion}

Adopting the view that it is the situational linguistic and schematic resources that provide not merely the frame but in effect the stuff of religious experiences, I suggest here that the rubric of "requisite experiences" may allow us to make use of certain kinds of religious literature from the imperial period, in the

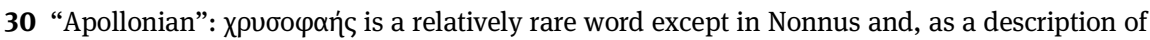
planets, in imperial-date astrological texts; the closest surviving parallel to this qualification of Apollo occurs in the four-line dedication of a golden wreath to him by T. Quinctius Flamininus

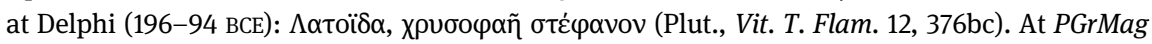
IV 458 the adjective is used as an epithet of Helios, as at Eur., Hec. 636 (lyric).

31 The papyrus reads $\varphi \iota \lambda \alpha \mu \alpha \gamma \varepsilon$, for which Preisendanz read $\varphi \iota \lambda \alpha i \dot{\mu} \alpha \tau \varepsilon$; K.F.W. Schmidt wanted to "re-apollinize" by reading $\varphi \iota \lambda \alpha$ ó $\mu \alpha \tau \varepsilon$, "chariot-loving”, a word that occurs precisely twice in Greek, in each case qualifying a city. 
present case, consciously innovative or idiosyncratic hymns, to infer an ideal response, which, I would urge, formed a significant element of the interpretative frames available for the formulation of experiences claimed as "religious" within each context. Privileged by the implied conditions of performance within a select group of cultivated connoisseurs, the hymns of Mesomedes deliberately dispense with "normative" genre-expectations in order to intimate a variety of impressions in rapid succession, impressions that in combination evoke a polyvalent, yet almost mystical, conception of divine action-in-the-world. The Orphic Hymns, on the other hand, uphold, even renew, a vision of an overwhelmingly vibrant polytheism, overflowing with energy and daring, and thus transforming an ancient tradition - albeit only within the confines of a sophisticated, like-minded performative group. While they acknowledged Greek hymns as a source of religious capital, the Greco-Egyptian practitioners who appropriated these fragments into their praxeis subordinated them to a larger, and on its own terms more effective, ritual project, namely direct intervention into the order of things, a project in which the notion of praise, central within the Greek tradition, rubs uneasily against the technology of high ritual realism. As mere quotations, the fragments lose their autonomy and take on the secondary role of items in a multi-cultural Universalinstrument. As such, it is appropriate that the audience was reduced to one, the practitioner himself.

\section{Bibliography}

\section{Sources}

Athanassakis, Apostolos N.; Wolkow, Benjamin M. (rev. tr., comm.) 2013. The Orphic Hymns.

Baltimore. Original ed. publ. by Athanassakis alone, Atlanta GA. 1977.

Behr, Charles A. 1986. Aelius Aristides, the Complete Works, 2: Orations XVII-LIII, 261-268.

Leiden.

Bortolani, Ljuba M. 2016. Magical Hymns from Roman Egypt: A Study of Greek and Egyptian

Traditions of Divinity. Cambridge.

Fayant, Marie-Christine 2014. Les Hymnes orphiques [Budé]. Paris.

Furley, William D.; Bremer, Jan Maarten (eds., comm.) 2001. Greek Hymns. 2 vols. STAC.

Tübingen. 9-10.

Heitsch, Ernst (ed.) 1963. Die griechischen Dichterfragmente der römischen Kaiserzeit ${ }^{2}$, vol. 1. Göttingen.

Kenyon, F.G. 1893. Greek Papyri in the British Museum. Catalogue with Texts, 1. London.

Lacarrière, Jacques (tr.) 1995. Orphée: Hymnes \& Discours sacrés. Paris.

Plassmann, Joseph 0. 1992. Orpheus: Altgriechische Mysterien ${ }^{2}$, with an Afterword by Fritz Graf. Munich. First publ. 1928, repr. of ed. 1. 1982. 
Preisendanz, Karl (ed., tr.) 1928-41. Papyri Graecae Magicae: Die griechischen Zauberpapyri. 3 vols. Leipzig; cited from second ed. in 2 vols. revised by A. Henrichs (Stuttgart, 1973-74, repr. Munich and Leipzig, 2001). Cited as PGrMag.

Regenauer, Janna 2016. Mesomedes: Übersetzung und Kommentar. Studien zur klassischen Philologie 175. Frankfurt a.M.

Ricciardelli, Gabriella (ed., tr., comm.). 2000a. Inni orfici. Rome. (repr. Milan. 2006 and 2012.) Russell, Donald A. et al. (eds.) 2016. In Praise of Asclepius: Aelius Aristides, Selected Prose Hymns. SAPERE 29. Tübingen.

Quandt, Wilhelm. 1955. Orphei hymni. ${ }^{2}$ Berlin. Ed. 1, 1941; ed. 2 reprinted unchanged 1962, 1973 and 2005.

Totti, Maria (ed.) 1985. Ausgewählte Texte der Isis- und Sarapis-Religion. Subsidia Epigraphica 12. Hildesheim.

\section{Literature}

Bélis, Annie 2003. 'Un lyrikos de l'époque des Antonins: Mésomède de Crète.' In La poésie grecque antique. Actes du $13^{e}$ colloque de la Villa Kérylos, 18-19 oct. 2002, ed. Jacques Jouanna, Jean Leclant. Paris. 223-235.

Bernabé Pajares, Alberto 2010. 'El himno órfico a Zeus: Vicisitudes literarias, ideológicas y religiosas.' In Orfeo y el orfismo: nuevas perspectivas, ed. Alberto Bernabé Pajares, Francesco Casadesús Bordoy, Marco Antonio Santamaría Álvarez. Alicante. URL: http://www.cervantesvirtual.com/nd/ark:/59851/bmcm04n6. 67-97. (Last consulted 8. 1.2018)

Bernabé Pajares, Alberto; Alvaro, M.J. et al. 1988. Orphei hymnorum concordantia. AlphaOmega, Reihe A 84. Hildesheim.

Bernabé Pajares, Alberto; Casadesús Bordoy, Francesco (eds) 2008. Orfeo y la tradición órfica: Un reencuentro. 2 vols. Madrid.

Brashear, William M. 1995. 'The Greek Magical Papyri: An Introduction and Survey; Annotated Bibliography (1928-1994)', ANRW II.18.5. 3380-3684.

Bremer, Jan Maarten 1998. 'The Greek Cultic Poetry: Some Ideas Behind a Forthcoming Edition', Mnemosyne ${ }^{4}$ 51.5. 513-524.

Bricault, Laurent 1996. Myrionymi: Les épiclèses grecques et latines d'Isis, de Sarapis et d'Anubis. Stuttgart.

Brumbaugh, Michael 2015. 'Making the Hymn: Mesomedean Narrative and the Interpretation of a Genre.' In Faulkner and Hodkinson 2015. 165-182.

Deshours, Nadine 2011. L'été indien de la religion civique. Scripta Antiqua 30. Bordeaux.

Downie, Janet 2013. At the Limits of Art: A Literary Study of Aelius Aristides' Hieroi Logoi. Oxford.

Faraone, Christopher A. 2000. 'Handbooks and Anthologies: The Collection of Greek and Egyptian Incantations in Late Hellenistic Egypt', Archiv für Religionsgeschichte 2.2. 195-214.

Faulkner, Andrew; Hodkinson, Owen (eds) 2015. Hymnic Narrative and the Narratology of Greek Hymns. Mnemosyne Suppl. 394. Leyden.

Fauth, Wolfgang 1983. s.v. 'Zagreus', PWRE IXA 2. 2221-2283.

Fitzgerald, Timothy 2000. 'Experience.' In Guide to the Study of Religion, ed. Willi Braun, Russell T. McCutcheon. London. 125-139. 
Fitzgerald, Timothy 2010. “"Experiences Deemed Religious”. Radical Critique or Temporary Fix? Strategic Ambiguity in Ann Taves' Religious Experience Re-Considered”, Religion 40. 296-299. doi-org/10.1016/j.religion.2010.09.005

Frankfurter, David 1995. 'Narrating Power: The Theory and Practice of the Magical historiola in Ritual Spells.' In Ancient Magic and Ritual Power, ed. Marvin Meyer, Paul Mirecki. RGRW 129. Leyden. 457-476.

Furley, William D. 1993. 'Types of Greek Hymns', Eos 81. 21-41.

Furley, William D. 1995. 'Praise and Persuasion in Greek Hymns', Journal of Hellenic Studies 115. 29-46.

Goeken, Johann 2007. 'Pourquoi furent composés les hymnes en prose d'Aelius Aristide?' In Lehmann 2007. 189-204.

Goeken, Johann 2016. 'Le corpus des hymnes en prose d'Aelius Aristide (Or. 37-46)'. In Aelius Aristide écrivain, ed. Laurent Pernot, Giancarlo Abbamonte, Mario Lamagna. Recherches sur le rhétoriques religieuses 19. Turnhout. 283-303.

Graf, Fritz 1992. 'Nachwort.' In Plassmann 1992, 161-175.

Graf, Fritz 2009. 'Serious Singing: The Ophic Hymns as Religious Texts', Kernos 22. 169-182.

Gschwantler, Kurt 2005. 'Statue der Göttin Isis.' In Meisterwerke der Antikensammlung. Vienna: Kunsthistorisches Museum, Vienna. 72-73.

Halfmann, Helmut 1990. 'Hymnoden von Asia in Kyzikos.' In Mysische Studien, ed. Elmar Schwertheim. Bonn. 21-26.

Herrero de Jáuragui, Miguel 2015. 'The Poet and his Addressees in Orphic Hymns.' In Faulkner and Hodkinson 2015. 224-243.

Hood, Ralph W. (ed.) 1995. Handbook of Religious Experience. Birmingham, AL.

Hopman-Govers, Marianne 2001. 'Le jeu des épithètes dans les Hymnes orphiques', Kernos 14. 35-49.

James, Wendy 2003. The Ceremonial Animal. Oxford.

Jiménez San Cristóbal, Ana Isabel 2008. 'Orfismo y dionisismo.' In Bernabé and Casadesús 2008. 697-727.

Kapferer, Bruce 1986. 'Performance and Structuring of Meaning and Experience.' In Turner and Bruner 1986. 188-203.

Kapferer, Bruce 1997. The Feast of the Sorcerer: Practices of Consciousness and Power. Chicago. Karanika, Andromache 2011. 'Homer the Prophet: Homeric Verses and Divination in the Homeromanteion.' In Sacred Words: Orality, Literacy and Religion, ed. A.P.M.H. Lardinois et al. Orality and Literacy in the Ancient World $8=$ Mnemosyne Suppl. 332. Leyden. 255-277.

Keil, Josef 1908. 'Zur Geschichte der Hymnoden in der Provinz Asia', Jahrbuch des Österreichischen Archäologischen Instituts 11. 101-109.

Lanna, Sara 2013. 'L'inno a Iside di Mesomede: Osservazioni sui vv.9-10.' In Studi di poesia greca tardoantica. Atti della giornata di studi, Firenze, 4 ott. 2012, ed. Daria Gigli Piccardi, Enrico Magnelli. Florence. 65-78.

Lattke, Michael 1991. Hymnus: Materialien zu einer Geschichte der antiken Hymnologie. Novum Testamentum et Orbis Antiquus 19. Göttingen.

Le Guen, Brigitte 2001. Les associations des technites dionysiaques à l'époque hellénistique. 2 vols. Nancy.

Lehmann, Yves (ed.) 2007. L'hymne antique et son public. Recherches sur les rhétoriques religieuses 7. Turnhout.

Lienhardt, Godfrey 1961. Divinity and Experience: The Religion of the Dinka. Oxford. 
Lonsdale, Steven H. 1995. 'Homeric Hymn to Apollo: Prototype and Paradigm of Choral Performance', Arion 3.1. 25-40.

Malaise, Michel 2005. Pour une terminologie et une analyse des cultes isiaques. Mémoires de la Classe des Lettres, sér. 3, 35. Brussels.

Martin, Craig 2016. 'Experience.' In The Oxford Handbook of the Study of Religion, ed. Michael Stausberg, Steven Engler. Oxford. 525-540.

Morand, Anne-France 2001. Études sur les Hymnes Orphiques. RGRW 143. Leyden.

Morand, Anne-France 2015. 'The Narrative Techniques of the Orphic Hymns.' In Faulkner and Hodkinson 2015. 209-223.

Murphy, Tim 2010. The Politics of Spirit: Phenomenology, Genealogy, Religion. Albany, NY.

Parker, Robert C.T. 2012. s.v. 'Hymns (Greek).' In Oxford Classical Dictionary ${ }^{4}$, ed. Simon Hornblower, Antony Spawforth. Oxford. 715-716.

Parker, Robert C.T. 2016. 'Religion in the Prose Hymns.' In Russell et al. 2016. 67-88.

Pernot, Laurent 2007. 'Hymne en vers ou hymne en prose? L'usage de la prose dans l'hymnographie grecque.' In Lehmann 2007. 169-188.

Petridou, Georgia 2015. Divine Epiphany in Greek Literature and Culture. Oxford.

Petsalis-Diomidis, Alexia 2010. 'Truly Beyond Wonders': Aelius Aristides and the Cult of Asklepios. Oxford.

Platt, Verity 2011. Facing the Gods: Epiphany and Representation in Graeco-Roman Art, Literature and Religion. Cambridge.

Pòrtulas, Jaume 2012. 'Cult Poetry in Archaic Grece.' In Approaches to Archaic Greek Poetry, ed. Xavier Riu, Jaume Pòrtulas. Messina. 221-248.

Proudfoot, Wayne 1985. Religious Experience. Berkeley.

Psaroudakes, Stelios 2018. 'Mesomedes' Hymn to the Sun: The Precipitation of Logos in the Melos'. In Music, Text, and Culture in Ancient Greece, ed. Tom Phillips, Armand d'Angour. Oxford. 121-134.

Quin, Michael J. 1843. Steam Voyages on the Seine, the Moselle and the Rhine, with Railroad Visits to the Principal Cities of Belgium. 2 vols. London.

Race, William H. 1982. 'Aspects of Rhetoric and Form in Greek Hymns', Greek, Roman and Byzantine Studies 23. 5-14.

Rappaport, Roy A. 1999. Ritual and the Religion in the Making of Humanity. Cambridge.

Ricciardelli, Gabriella 1995. 'Inni orfici: el proemio e la silloge', Bollettino Classico 16. 63-68. Ricciardelli, Gabriella 2000b. 'Gli Inni orfici tra Orfeo e Dioniso', AION(filol) [Naples: Istituto universitario orientale] 22. 313-326.

Ricciardelli, Gabriella 2008. 'Los himnos órficos.' In Bernabé and Casadesús 2008. 325-348.

Rudhardt, Jean 1991. 'Quelques réflexions sur les hymnes orphiques.' In Orphisme et Orphée, en l'honneur de Jean Rudhardt, ed. Philippe Borgeaud. Recherches et Rencontres: Publications de la Faculté des lettres de Genève 3. Geneva. 263-283.

Rudhardt, Jean 2008. 'Recherches sur les Hymnes orphiques.' In Jean Rudhardt, Opera inedita, ed. Philippe Borgeaud, Vinciane Pirenne-Delforge. Suppl. Kernos 19. Liège. 165-325.

Russell, David A. 1990. 'Aristides and the Prose Hymn.' In Antonine Literature, ed. David A. Russell. Oxford. 199-219.

Sax, William S.; Quack, Johannes; Weinhold, Jan (eds) 2010. The Problem of Ritual Efficacy. Oxford.

Scott, Joan W. 1992. 'Experience.' In The Feminists Theorize the Political, ed. Judith Butler, Joan W. Scott. New York. 22-40. 
Sfameni Gasparro, Giulia 2013. 'Dioniso tra polinomia ed enoteismo: il caso degli Inni Orfici.' In Redefining Dionysos, ed. Alberto Bernabé Pajares, Miguel Herrero de Jáuregui, Ana Isabel Jiménez San Cristóbal. MythosEikonPoiesis 5. Berlin. 433-451.

Sharf, Robert H. 1998. 'Experience.' In Critical Terms for Religious Studies, ed. Mark C. Taylor. Chicago. 94-116.

Sharf, Robert H. 2000. 'The Rhetoric of Experience and the Study of Religion', Journal of Consciousness Studies 7 (11-12). 267-287.

Shuttleworth Kraus, Christina 2002. 'Introduction: Reading Commentaries/Commentaries as Reading.' In The Classical Commentary: Histories, Practices, Theory, ed. Christina Shuttleworth Kraus, Roy K. Gibson. Mnemosyne Supplement 232. Leyden. 1-27.

Stark, Rodney A. 1965. 'A Taxonomy of Religious Experience', Journal for the Scientific Study of Religion 5. 97-116.

Stark, Rodney A. 1999. 'A Theory of Revelations', Journal for the Scientific Study of Religion 38. 287-308.

Taves, Ann 2009. Religious Experience Re-Considered: A Building-Block Approach to the Study of Religion and Other Special Things. Princeton.

Taves, Ann 2016. Revelatory Events: Three Case-Studies of the Emergence of New Spiritual Paths. Princeton.

Thraede, Konrad 1994. s.v. 'Hymnus', Reallexikon für Antike und Christentum 16. 915-945. Turner, Victor 1974. Dramas, Fields, and Metaphors: Symbolic Action in Human Society. Ithaca. Turner, Victor; Bruner, Edward M. (eds) 1986. The Anthropology of Experience. Urbana. Van Nijf, Onno 1997. The Civic World of Professional Associations in the Roman East. Amsterdam.

Várhelyi, Zsuszanna 2001. 'Magic, Religion and Syncretism in the Oracle of Claros.' In Between Magic and Religion: Interdisciplinary Studies in Ancient Mediterranean Religion and Society, ed. Sulochana Asirvatham et al. Lanham. 13-31.

Whitby, Mary 1994. 'From Moschus to Nonnus: The Evolution of the Nonnian Style.' In Studies in the Dionysiaka of Nonnus, ed. Neil Hopkinson. Cambridge Philological Society Suppl. 17. Cambridge. 99-155.

Wünsch, Richard 1914. s.v. 'Hymnos', PWRE 9.1. 140-183. 